\title{
The ecosystem service of sense of place: benefits for human well-being and biodiversity conservation
}

\author{
ANNA HAUSMANN ${ }^{1 *}$, ROB SLOTOW ${ }^{12}$, JONATHAN K. BURNS ${ }^{3}$ AND ENRICO DI MININ ${ }^{14}$ \\ ${ }^{1}$ Amarula Elephant Research Programme, School of Life Sciences, University of KmaZulu-Natal, Durban 4041, South Africa, ${ }^{2}$ Department of \\ Genetics, Evolution and Environment, University College, London, UK, ${ }^{3}$ Department of Psychiatry, Nelson R. Mandela School of Clinical \\ Medicine, University of KmaZulu-Natal, Durban 4041, South Africa and ${ }^{4}$ Finnish Centre of Excellence in Metapopulation Research, Department \\ of Biosciences, University of Helsinki, 00014 Helsinki, Finland
}

Date submitted: 24 February 2015; Date accepted: 13 August 2015; First published online 16 September 2015

\section{SUMMARY}

Assessing the cultural benefits provided by non-market ecosystem services can contribute previously unknown information to supplement conservation decisionmaking. The concept of sense of place embeds all dimensions of peoples' perceptions and interpretations of the environment, such as attachment, identity or symbolic meaning, and has the potential to link social and ecological issues. This review contains: (1) an evaluation of the importance of sense of place as an ecosystem service; and (2) comprehensive discussion as to how incorporating sense of place in an evaluation can uncover potential benefits for both biodiversity conservation and human well-being. Sense of place provides physical and psychological benefits to people, and has neglected economic value. The biodiversityrelated experiences are essential components of the service that need to be further explored. A conceptual framework was used to explore how the existing knowledge on sense of place derived from other fields can be used to inform conservation decision-making, but further research is needed to fill existing gaps in knowledge. This review contributes to a better understanding of the role biodiversity plays in human well-being, and should inform the Intergovernmental Platform on Biodiversity and Ecosystem Services (IPBES).

Keymords: biodiversity conservation planning, cultural service, ecosystem service, Intergovernmental Platform on Biodiversity and Ecosystem Services (IPBES), sense of place

\section{INTRODUCTION}

Globally, habitat transformation is causing unprecedented loss of biodiversity (Butchart et al. 2010). In turn, this affects ecosystem functioning and stability, the flow of ecosystem

\footnotetext{
*Correspondence: Anna Hausmann Tel: +27 721713245 e-mail: anna.hausmann87@gmail.com

Supplementary material can be found online at http://dx.doi.org/10.1017/S0376892915000314
}

services and human well-being (Foley et al. 2005; Cardinale et al. 2012). Conflicts between biodiversity conservation and human development needs, which are driving habitat transformation and biodiversity loss, are difficult to resolve (Chan et al. 2007).

In order to identify beneficial solutions for all involved, conservation agendas are focusing on ecosystem services (Balvanera et al. 2001; Armsworth et al. 2007). Ecosystem services are 'the benefits people obtain from ecosystems' (MA [Millennium Ecosystem Assessment] 2005; p.1), which depend on biodiversity (Mace et al. 2012) and sustain human well-being in everyday life (MA 2005). A number of assessments have combined biodiversity conservation and sustainable development objectives (see White et al. 2012; Bateman et al. 2013). However, studies on the spatial congruence between ecosystem services and biodiversity show that priority areas do not always match (see for example, Chan et al. 2006; Anderson et al. 2009; Egoh et al. 2009; Di Minin et al. 2013b). In addition, gaps in ecosystem services science (Carpenter et al. 2009), and lack of political support (Chan $e t$ al. 2007), challenge implementation on the ground (Tallis et al. 2008). Consequently, new information is needed to evaluate ecosystem services (Carpenter et al. 2009) and assess their contribution to help identify strategies that benefit both biodiversity conservation and human well-being (Chan et al. 2007; Norgaard 2010; Saunders 2013).

Ecosystems provide material (for example, water availability, crop diversity, and climate regulation) and nonmaterial (such as cultural, recreational, and spiritual) benefits to people (MA 2005). The evaluation of material services is crucial to inform the society about the importance of natural capital (Costanza \& Daly 1992). Importantly, the evaluation of material services provides information that can be used to inform conservation planning (Egoh et al. 2007; Tallis et al. 2008) and decision-making processes (Daily et al. 2009; Bateman et al. 2013). However, the evaluation of the intangible benefits of most of the nonmaterial, cultural, services has been largely overlooked (MA 2005).

By bridging the gap between different academic disciplines, the evaluation of cultural services may help inform real-world decision-making (Milcu et al. 2013; Saunders 2013). Among cultural services, 'sense of place', which people develop in connection with ecosystems (Russell et al. 2013), has been 
indicated as a concept that may potentially bridge existing gaps between ecosystem science and environmental management (Williams \& Stuart 1998). By understanding, anticipating, and responding to peoples' relationships with places, managers are better equipped to develop management activities that will avoid conflict and gain public support (Williams \& Stuart 1998). Sense of place is, however, one of the most neglected cultural services and information on how to integrate it into conservation decision-making is scarce (MA 2005).

We reviewed the existing literature on sense of place, with an aim to identify the potential contributions of sense of place to both human well-being and biodiversity conservation. We started by defining sense of place in fields outwith conservation science. We reviewed the literature to: (1) clarify the importance (social and economic benefits) of sense of place as an ecosystem service, (2) discuss how sense of place has been accounted for in conservation science, and (3) identify how to further integrate sense of place values into conservation decision-making.

\section{METHODS}

To explore the implications of sense of place in biodiversity conservation, we searched existing publications on sense of place, using the Thomson Reuters' Web-of-Science database (accessed 1 September 2014). Since the term 'place attachment' has also been used as an alternative term for sense of place (Brown \& Raymond 2007), this was also included in our literature search. We used the phrase 'TOPIC: (('sense of place') OR ('place attachment'))' as a baseline for the search (1441 results). In order to select papers that looked at sense of place in biodiversity conservation, we also included in the search AND 'conservation' as TOPIC (114 results). We subsequently refined the results by using 'biodiversity' (21 results) and 'ecosystem service*' (11 results) and 'management' (57 results). We thus identified a total of 62 unique articles (see Supplementary material for the complete list); those that were most relevant are cited. In each of the studies, we looked at (1) implications for human well-being and biodiversity conservation; and (2) insights addressing gaps in conservation science. Next, we identified gaps in conservation science, and issues related to the integration of sense of place in conservation decision making. The resulting information on gaps was used to develop a conceptual framework (Fig. 1), summarizing insights gained from other disciplines, and emphasizing ways sense of place may be incorporated in conservation decision-making to promote positive benefits for both biodiversity conservation and human well-being.

\section{Sense of place}

Sense of place represents all dimensions of human perception and interpretation of the environment in an emotional, spiritual and cognitive way (Tuan 1977; Jorgensen \& Stedman 2006). People develop a sense of place as a result of biological, individual and sociocultural processes that take place while people experience (namely by interacting, knowing, perceiving, or living; Russell et al. 2013) the physical environment (Table 1). In the Millennium Ecosystem Assessment, sense of place was referred to as the relationship between people and ecosystems, this relationship representing a natural condition indispensable for human existence (MA 2005). However, the concept has had a long history of application in multiple disciplines, and has only recently been recognized as an ecosystem service (MA 2005).

The terminology surrounding sense of place varies across different disciplines (Table 2). For example, in environmental psychology and sociological studies, sense of place is referred to as peoples' attachment to, identification with, and dependence on places, and has been used to describe connections with, and perceptions of, environments affecting human behaviour (Stedman 2002). In human geography, sense of place entails all the meanings that people assign to places, which define the perceived value of their attributes and appearance (Tuan 1990). In health sciences, peoples' connection with the natural environment has been described as a biologically-based condition, essential for human health (such as mental health and recovery; Maller et al. 2006). In ecosystem management, sense of place refers to public attitudes toward the environment and its management (for example in urban planning, natural resource management, and land-use planning), and has been used to assess social impacts of specific management decisions (Bauer et al. 2009). Finally, sense of place plays a key role in tourism development, and has been studied to understand its contribution to tourists' perceived value of experience, expectations, and satisfaction in relation to a specific destination (Kil et al. 2012).

\section{Health benefits}

Contact with nature promotes physical, mental and psychological well-being, enhancing peoples' assessment of quality of life in ways that cannot be satisfied by alternative means (Abraham et al. 2010; Maller et al. 2006; Russell et al. 2013). For instance, exposure to nature has been shown to promote recovery from surgery (Ulrich 1984) and lower blood pressure (Lohr \& Pearson-Mims 2006); relieve stress (Leather et al. 1998); increase positive mood (Maller et al. 2006); reduce mental fatigue (Staats et al. 2003); reduce crime and the tendency for aggressive behaviour (Kuo \& Sullivan 2001); promote social integration (Kweon et al. 1998); and contribute to the integrity of a personal or community identity (Horwitz et al. 2001; Maller et al. 2006). These benefits are received by people everywhere, by interacting with nature in a variety of environments, from urban areas (such as public gardens and parks; Tzoulas et al. 2007), to countryside (for example cultural landscapes; Phillips 1998) and natural environments (or wilderness; Fredrickson \& Anderson 1999). For example, experiencing solitude in wilderness areas enhances self-perception, personal fulfilment and promotes emotional, physical and intellectual 
Figure 1 Conceptual framework incorporating sense of place in conservation decision-making; pathways outline potential ways to mitigate threats to biodiversity conservation.

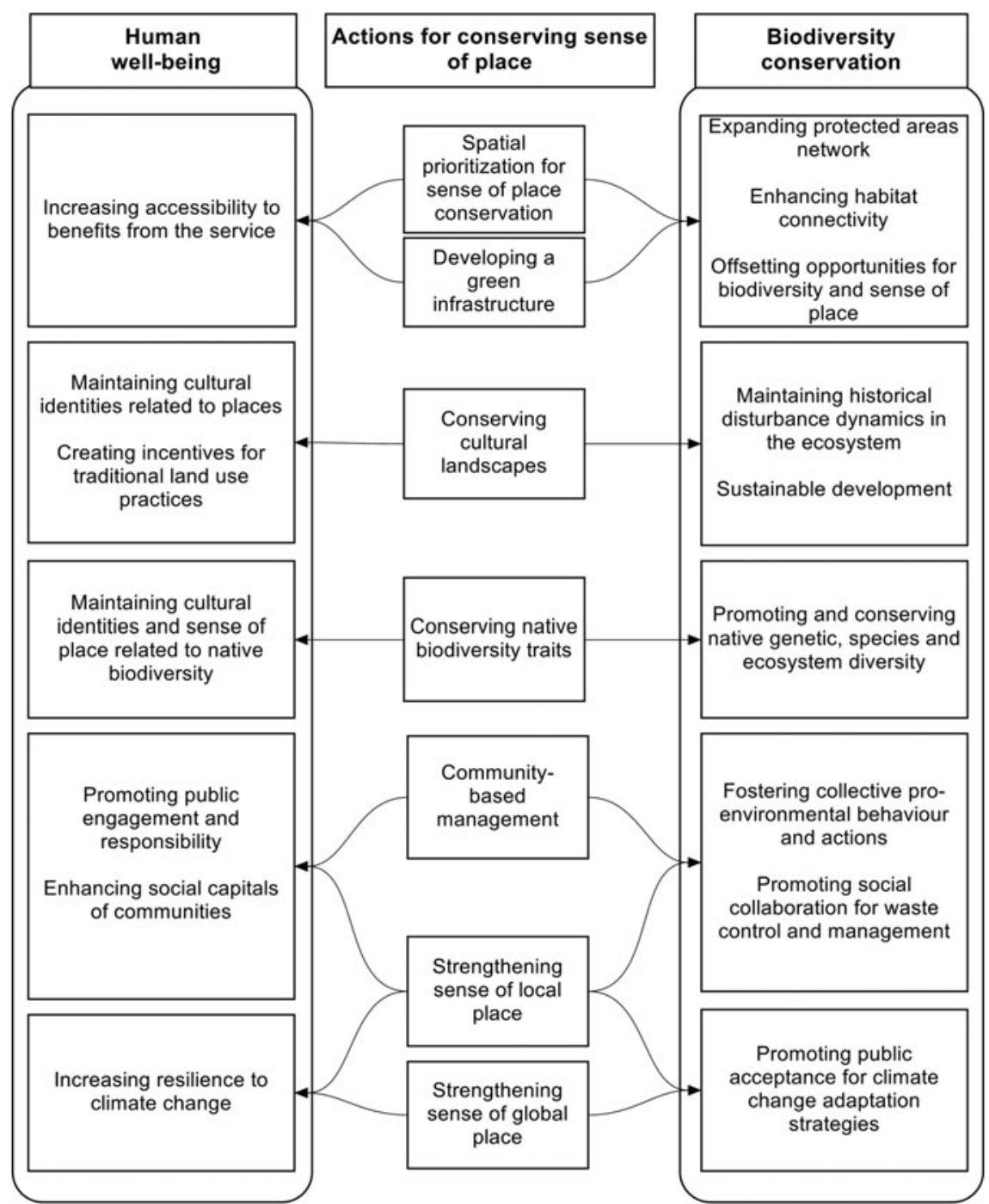

improvements (Fredrickson \& Anderson 1999). Experiencing wilderness has been used as a therapy for rehabilitating adolescents with emotional and behavioural problems (such as impulsivity, suicidal thoughts, and drug and alcohol use; Harper et al. 2007). Conversely, urban environments seem to be associated with a number of negative effects on human health. Being born and raised in an urban environment, for example, increases individual risk for anxiety, and depressive and psychotic disorders (Pedersen \& Mortensen 2001; Weich et al. 2006).

Moreover, people obtain benefits by contact with nature either directly, for example having indoor plants at the workplace (Larsen et al. 1998), a view from a window (Ulrich 1984; Leather et al. 1998), and/or actively experiencing nature through recreation, or indirectly by knowing its existence in the world (Russell et al. 2013). In particular, understanding sense of place as self-perception in a global environment has been suggested as critical for further studies, as it amplifies the importance of sense of place benefits from a local to a global scale (Devine-Wright 2013).

\section{Economic benefits}

In economics, ecosystems are referred to as 'natural capital' and are evaluated according to the goods and services they provide to individuals and societies (Costanza \& Daly 1992). The economic values of sense of place have not yet been assessed, resulting in an incomplete evaluation of the natural capital (MA 2005). The economic value of sense of place, as for other cultural services (Chan et al. 2012), has been overlooked due to the difficulties related to its quantitative assessment (Williams \& Stewart 1998).

Cultural services have been mainly evaluated for their recreational and aesthetic services (see Chan et al. 2006; Bateman et al. 2013), neglecting the sense of place value (MA 2005). For example, the aesthetic perception of ecosystem is influenced by components of attachment and emotions (Ulrich 1983), which might be related to observers' expressions of its sense of place. Moreover, sense of place has been shown to drive tourists' preferences for the choice of destination ( $\mathrm{Um} \&$ Crompton 1990), and the intention to revisit (Kil et al. 2012). However, there is no empirical evidence about the ability of 
Table 1 Components of the development of sense of place and attributes of each component affecting peoples' perspectives.

\begin{tabular}{|c|c|c|c|c|}
\hline Component & Attribute & Definition & Evidence in literature & Reference \\
\hline \multirow[t]{3}{*}{ People } & $\begin{array}{l}\text { Biological / } \\
\text { evolutionary }\end{array}$ & $\begin{array}{l}\text { Psycho-evolutionary } \\
\text { theories explaining } \\
\text { peoples' preferences for } \\
\text { certain types of natural } \\
\text { landscapes as the result of } \\
\text { evolutionary processes } \\
\text { that still drive the } \\
\text { selection of places } \\
\text { providing restoration and } \\
\text { refuge }\end{array}$ & $\begin{array}{l}\text { People's preference for } \\
\text { natural over built } \\
\text { landscapes, regardless of } \\
\text { people's cultural origin; } \\
\text { preferences for } \\
\text { savannah-like } \\
\text { environments }\end{array}$ & $\begin{array}{l}\text { Kaplan and Kaplan 1989; } \\
\text { Kellert 1995; Grinde and } \\
\text { Patil } 2009\end{array}$ \\
\hline & Personal experience & $\begin{array}{l}\text { Personal, intimate } \\
\text { experiences at different } \\
\text { dimensions (namely } \\
\text { living within, knowing, } \\
\text { perceiving, and } \\
\text { interacting) }\end{array}$ & $\begin{array}{l}\text { The longer the experience } \\
\text { of a place, the higher is } \\
\text { the level of attachment to } \\
\text { it (by accumulating and } \\
\text { deepening personal } \\
\text { meanings, memories and } \\
\text { feelings) }\end{array}$ & $\begin{array}{l}\text { Tuan 1977; Low and } \\
\text { Altman 1992; Schroeder } \\
\text { 1996; Russell et al. } 2013\end{array}$ \\
\hline & Socio-cultural context & $\begin{array}{l}\text { Different people share } \\
\text { meanings and symbols of } \\
\text { a place as a consequence } \\
\text { of interpersonal } \\
\text { interactions with the } \\
\text { particular cultural group } \\
\text { they belong to }\end{array}$ & $\begin{array}{l}\text { Heterogeneity in } \\
\text { preferences and } \\
\text { attachment to places } \\
\text { according to cultural } \\
\text { origin, ethnic and } \\
\text { religious association, } \\
\text { education and occupation }\end{array}$ & $\begin{array}{l}\text { van den Berg et al. } 1998 ; \\
\text { Urquhart and Acott } 2014\end{array}$ \\
\hline \multirow[t]{2}{*}{ Ecosystem } & $\begin{array}{l}\text { Physical attributes } \\
\text { and features }\end{array}$ & $\begin{array}{l}\text { Physical attributes/ features } \\
\text { of a place influences the } \\
\text { symbolic meanings of the } \\
\text { landscape which are in } \\
\text { turn associated with } \\
\text { evaluations and } \\
\text { attachments }\end{array}$ & $\begin{array}{l}\text { Preferences for park-like } \\
\text { natural-looking } \\
\text { landscapes that include } \\
\text { canopy trees or water } \\
\text { features; allow views out } \\
\text { across the landscape }\end{array}$ & $\begin{array}{l}\text { van den Berg et al. 1998; } \\
\text { Stedman 2003; }\end{array}$ \\
\hline & $\begin{array}{l}\text { Ecosystem } \\
\text { appearance/ } \\
\text { ecological condition }\end{array}$ & $\begin{array}{l}\text { Ecological qualities and } \\
\text { aesthetic aspect of the } \\
\text { environments (such as } \\
\text { complexity, coherence, } \\
\text { disturbance), influencing } \\
\text { people's landscape } \\
\text { preferences and } \\
\text { attachment }\end{array}$ & $\begin{array}{l}\text { Preference for 'healthy' } \\
\text { looking landscapes; } \\
\text { perceived concerns about } \\
\text { environmental } \\
\text { degradation }\end{array}$ & $\begin{array}{l}\text { Ulrich 1983; Kaltenborn } \\
\text { 1998; Brehm et al. 2013; }\end{array}$ \\
\hline
\end{tabular}

aesthetic and recreational values to act as surrogates of sense of place in the assessment of the natural capital. In other words, the use of these values to assess the economic importance of ecosystems may overlook other aspects that sense of place in turn entails.

Sense of place includes other aspects of economic benefits, which are not confined to recreational and aesthetic values. For example, contact with nature at the workplace increases work productivity (Leather et al. 1998) and reduces health care costs by preventing mental illness (Dewa et al. 2004). Moreover, the improvement of social connections (Fredrickson \& Anderson 1999), as a result of sense of place development, enhances the value of social capital (namely social collaborations that encourage collective and productive activities; Lewicka 2005), by encouraging interpersonal bonds between people in groups and communities (Pretty \& Ward 2001). This strengthens peoples' commitment to places, enhancing pro-environmental behaviour, responsible use of resources and waste reduction (Pretty \& Ward 2001; Ramkissoon et al. 2012).

\section{Use in biodiversity conservation and management}

Sense of place plays a key role in predicting and promoting public support for conservation in diverse socioecological contexts (Garcia-Llorente et al. 2012; Lokhorst et al. 2014). In conservation science, sense of place has been explored as part of attitudes toward accepting conservation policies (for example, conservation easements in private lands; Farmer et al. 2011), and supporting environmental conservation (Garcia-Llorente et al. 2012; Lokhorst et al. 2014). Connection 
Table 2 Concepts related to sense of place that have been used in different disciplines to describe various aspects of the human relationship with the natural environment.

\begin{tabular}{|c|c|c|c|c|}
\hline Discipline & Concept & Description & Context & References \\
\hline Ecosystem service & Sense of place & $\begin{array}{l}\text { The provisioning of } \\
\text { opportunities for people } \\
\text { to develop a sense of } \\
\text { connectedness and } \\
\text { self-fulfilment }\end{array}$ & $\begin{array}{l}\text { Providing benefits to } \\
\text { people }\end{array}$ & MA 2005 \\
\hline $\begin{array}{l}\text { Environmental } \\
\text { psychology, } \\
\text { sociology }\end{array}$ & $\begin{array}{l}\text { Sense of belonging; } \\
\text { sense of identity; } \\
\text { sense of community }\end{array}$ & $\begin{array}{l}\text { Respectively: positive and } \\
\text { affective bonds with } \\
\text { places; beliefs about the } \\
\text { relationship between } \\
\text { self-definition and places; } \\
\text { degree to which a place is } \\
\text { perceived to sustain a } \\
\text { specific } \\
\text { behaviour/activity }\end{array}$ & $\begin{array}{l}\text { Exploring dimensions } \\
\text { of people-place } \\
\text { relationship. } \\
\text { Reduction of, and } \\
\text { recovery from, } \\
\text { stress; psychological } \\
\text { integrity and } \\
\text { preventing mental } \\
\text { illnesses }\end{array}$ & $\begin{array}{l}\text { Kaplan and Kaplan 1989; } \\
\text { Low and Altman 1992; } \\
\text { Cuba and Hummon 1993; } \\
\text { Stedman 2002; Gosling } \\
\text { and Williams 2010; } \\
\text { Lopez-Mosquera and } \\
\text { Sanchez 2012; van Riper } \\
\text { and Kyle 2014 }\end{array}$ \\
\hline $\begin{array}{l}\text { Human geography, } \\
\text { philosophy and } \\
\text { religion }\end{array}$ & $\begin{array}{l}\text { Topophilia; sense of } \\
\text { meanings }\end{array}$ & $\begin{array}{l}\text { What a place symbolizes to } \\
\text { people, even just from } \\
\text { knowing that the place } \\
\text { exists }\end{array}$ & $\begin{array}{l}\text { Relation between } \\
\text { preferences, beliefs } \\
\text { and perception of } \\
\text { place-related values }\end{array}$ & $\begin{array}{l}\text { Tuan 1977; Tuan 1990; } \\
\text { Kaltenborn 1998; Brown } \\
\text { and Raymond 2007; } \\
\text { Brehm et al. 2013; }\end{array}$ \\
\hline Health sciences & Biophilia & $\begin{array}{l}\text { Innate love and desire of } \\
\text { contact with nature }\end{array}$ & $\begin{array}{l}\text { Contact with nature in } \\
\text { recovery from } \\
\text { diseases and staying } \\
\text { healthy }\end{array}$ & $\begin{array}{l}\text { Ulrich 1984; Kellert 1995; } \\
\text { Maller et al. 2006; Grinde } \\
\text { and Patil 2009; Abraham } \\
\text { et al. } 2010\end{array}$ \\
\hline $\begin{array}{l}\text { Environmental } \\
\text { resource } \\
\text { management }\end{array}$ & $\begin{array}{l}\text { Sense of commitment; } \\
\text { Sense of ownership }\end{array}$ & $\begin{array}{l}\text { Judgments of the perceiving } \\
\text { quality of an environment } \\
\text { and its management }\end{array}$ & $\begin{array}{l}\text { Policy making; } \\
\text { conflict avoidance }\end{array}$ & $\begin{array}{l}\text { Bauer et al. 2009; Buijs et al. } \\
\text { 2009; De Groot 2012; } \\
\text { Htun et al. 2012; Bendt } \\
\text { et al. 2013; Larson } \text { et al. } \\
\text { 2013; Lokhorst } \text { et al. } 2014\end{array}$ \\
\hline Tourism and leisure & Sense of nourishment & $\begin{array}{l}\text { Perceived utilitarian value } \\
\text { of a place and its ability to } \\
\text { satisfy an individual's } \\
\text { needs }\end{array}$ & Choice of destination & $\begin{array}{l}\text { Kil et al. 2012; Ramkissoon } \\
\text { et al. 2012; Cheng et al. } \\
2013\end{array}$ \\
\hline
\end{tabular}

to nature increases peoples' perceptions of sense of place, promoting personal involvement in conservation (Lokhorst et al. 2014). In urban areas, green spaces (like public parks, private gardens, or allotments for horticulture) provide access to nature and sense of place (van Riper et al. 2012; Meurk et al. 2013), increasing awareness for environmental conservation (Bendt et al. 2013), and social collaboration for their management (Andersson et al. 2007; van Wyk et al. 2014). Moreover, the conservation of soundscapes related to sense of place (such as natural quietness or the sounds of wildlife) may be a way to alleviate human pressure on ecosystems and promote biodiversity conservation (Dumyahn \& Pijanowski 2011). Communities that perceived such values and understood the threats to sense of place were helpful in informing land-use planning (Brown \& Raymond 2007), and identifying sites of environmental concern (Raymond et al. 2009).

One of the main issues hindering the integration of sense of place into ecosystem management is the high variability in how people perceive the environment (which may vary according to cultural background or personal experience; Borrie \&
Birzell 2001). Insights designed to overcome this issue may be found in previous studies (see Sevenant \& Antrop 2010; Di Minin et al. 2013a), where latent class analysis was used to account for heterogeneity when exploring people preferences for environmental attributes. A latent class model implies that preferences are not unique to individuals, but belong to a finite and identifiable number of homogeneous classes of preferences. Individual membership of a class is explained by the sociodemographic profile (Boxall \& Adamowicz 2002). However, the application of latent class modelling to explain variability in sense of place perceptions still needs to be explored.

Another issue is related to the unclear relationship between sense of place and biodiversity (Williams \& Stuart 1998). Horwitz et al. (2001) stated that biodiversity, and its spatially distinctive features (such as species endemism, genetic diversity, and species abundance), is essential if ecosystems are to provoke attachment and stimulate an individual's identification with a particular place. Attractive landscapes elicit stronger emotional responses (Kaltenborn 1998; Larson et al. 2013), while interest in a particular species (such as 
charismatic megafauna) or ecosystems (like wilderness areas or national parks) is positively related to peoples' attachment to and willingness to conserve such items (Kaltenborn 1998; Martín-López et al. 2007). Although people recognize the intrinsic value of biological diversity (Martín-López et al. 2007), Larson et al. (2013) found that biodiversity was not valued by people for sense of place.

Evidence suggests that playing and exploring in natural environments during childhood may lead to the development of a sense of place and raise environmental awareness (Measham 2006). At the same time, human geographers describe sense of place as a centre of meanings developed by experiencing environments (Tuan 1977). While people can experience the environment through knowing, perceiving, interacting and living within it (Russell et al. 2013), the characteristics or activities associated with natural environments (such as fishing, hunting, or beauty of landscape) are also important to establishing a sense of place (Larson et al. 2013). Biodiversity features (for example species or ecosystems), and physical attributes related to natural environments, may also affect the way people develop a sense of place.

Interests in species and landscapes are expressions of perceived benefits (such as stress relief; Hartig \& Staats 2006) and reflect demand for cultural services (Cardinale et al. 2012) like sense of place. Preferences and willingness to pay are often used to assess the economic importance of perceived values for biodiversity (Martín-López et al. 2007; Di Minin et al. $2013 a$ ), and may be explored to assess the value of sense of place for biodiversity-related experiences. There is guidance to quantitatively assess sense of place (Mendoza \& MorenAlegret 2013) and estimate the economic value of cultural services (Chan et al. 2012). Among these, stated preferences methods (Adamowicz et al. 1998), used in environmental economics, have been suggested for estimating the marginal utility value of non-marketed goods and services (see Chan et al. 2012). These approaches can be applied to assess what people value most highly for sense of place when experiencing ecosystems.

\section{Threats, actions and sense of place}

Habitat destruction, overexploitation of resources, species introduction, pollution (Diamond 1984), and climate change (Heller \& Zavaleta 2009) are major drivers of biodiversity loss. We developed a conceptual framework (Fig. 1) of where sense of place could be included in conservation decision-making, and how it could be used to potentially mitigate threats to biodiversity conservation.

Sense of place development depends on the environment (namely physical features and attributes; an ecosystem's appearance and conditions), and is therefore also subject to threats affecting biodiversity. For example, land transformation occurring in 'special' places for sense of place (visited for recreational purposes; Kil et al. 2012), as well as loss of access to traditional place-related lifestyles (resources harvesting or spiritual and religious symbolic meanings; Alkan et al. 2009) may negatively affect individual psychology and a community's cultural values (Devine-Wright 2009). Alien plant invasion can affect environmental features and landscape appearance (by for example increasing soil erosion; Pejchar \& Mooney 2009), affecting traditional uses and customs connected to places (MA 2005). Pollution may also negatively affect sense of place, including exposure to noise pollution (Dumyahn \& Pijanowski 2011), or perceptions of environmental risks and concern for the future (Bickerstaff 2004). Climate change causes environmental changes (such as rising sea levels, increasing temperatures, and extreme weather events) that alter the physical characteristics of places, causing both identity and emotional disruptions between people and ecosystems (Reser et al. 2011).

Understanding how people respond to environmental changes (impacts on psychological health and well-being, response at local, national and global scales; Fresque-Baxter \& Armitage 2012; Devine-Wright 2013) is critical in order to identify management actions for adaptation (such as adjustments of structures, processes and practices). Moreover, it has the potential to provide new conceptual understandings that may help build resilience of both human and ecological systems (Devine-Wright 2013). Integrating sense of place into ecosystem management may help identify opportunities that both mitigate threats to biodiversity, and foster human wellbeing in ecosystem management (Fig. 1).

Mapping communities' sense of place (see Raymond et al. 2009) could help identify human-valued priority areas, such as 'critical natural capital', that may have been overlooked (Chiesura \& De Groot 2003) (Fig. 1). For example, recreational sites provide access to sense of place (Kil et al. 2012), and recreation demonstrates increased value of lands, provides competitive financial support to local stakeholders, and improves species diversity and conservation (Bateman et al. 2013; Di Minin et al. 2013b). Moreover, companies transforming natural habitats to alternative land uses (such as mining) could help conserve and enhance the service in other areas (McKenney \& Kiesecker 2010), thus compensating for habitat destruction (Fig. 1).

In urban planning, the development of a green infrastructure fosters psychological well-being by providing daily access to natural settings and sense of place (Maller et al. 2006; Tzoulas et al. 2007; Bendt et al. 2013), while ensuring a range of ecosystem services in urban areas (such as air filtration, microclimate regulation, and noise reduction; Gaston et al. 2013). Urban green spaces may enhance biodiversity through the promotion of ecological corridors and habitat connectivity (Rudd et al. 2002), as well as providing a refuge for native biodiversity (Goddard et al. 2010). Psychological benefits of green spaces increase with species richness (Fuller et al. 2007). Management strategies enhancing biological diversity (such as mosaics of habitat patches; Thwaites et al. 2005) and sense of place experiences in urban green space, could contribute to both human well-being and biodiversity conservation (Fig. 1). 
In rural areas, the promotion of low impact, traditional land uses (such as subsistence agriculture and small-scale farming) could also promote human well-being through sense of place (Phillips 1998) and sustainable development (Halladay \& Gilmour 1995) (Fig. 1). Cultural landscapes represent those areas where human influence (traditional use of land and resources; Urquhart \& Acott 2014) has been part of ecosystem dynamics over the centuries, affecting landscape appearance (Phillips 1998), and species adaptation and diversity (Halladay \& Gilmour 1995), while maintaining ecological processes (nutrient cycling and connectivity). This is particularly important in developing countries, where the maintenance of traditional systems would help create incentives for traditional land-use practices (Halladay \& Gilmour 1995). Enhancing the value of native biodiversity for sense of place experiences could help identify critical native species, such as local cultivar varieties for agricultural practices (Perreault 2005) or wildlife for ecotourism (Martín-López et al. 2007; Di Minin et al. 2013a), and enhance their conservation (Fig. 1).

Globally, sense of place has the potential to contribute to actions for climate change adaptation (by increasing the network of nature reserves, alleviating pressure on land use practices, and creating culturally appropriate management interventions; Heller \& Zavaleta 2009). However, of greater importance is the value of the collective actions and pro-environmental behaviours that sense of place, at a local (neighbourhood) and global scale, elicits in people (Lewicka 2005). Moreover, the development of a sense of 'global place' (Feitelson 1991) increases public concern for worldwide environmental issues, such as environmental changes (Devine-Wright 2013) and land transformations (Foley et al. 2011), enhancing social collaborations and public acceptance of management intervention for global resilience goals (Devine-Wright 2013).

Integrating sense of place in community-based management (Manzo 2006) and environmental impact assessment (Kaltenborn 1998) (Fig. 1) provides an opportunity to tap into peoples' attachment and stimulate pro-environmental behaviours (Brehm et al. 2013). Involving local people in decision-making reduces conflicts with communities (Chan et al. 2007) and provides support to the long-term success of conservation actions (Tallis et al. 2008). This is relevant in avoiding public opposition to environmental development in places considered important for sense of place (referred as the 'not in my backyard' [NIMBY] attitude; Devine-Wright 2009). This reaction may be the result of imposed changes, often unrelated to local identities, and may generate conflicts between institutions, conservation and people (DevineWright 2009).

While conserving sense of place may produce positive benefits (Fig. 1), peoples' preferences for environmental attributes and qualities may, in some cases, be misaligned with biodiversity conservation objectives (Kerley et al. 2003). This is the case, for example, with species introduction (ornamental plants or horticulture; Reichard \& White 2001), human-wildlife conflict (involving overkilling of predators to avoid livestock predation, concerns for the future, and concerns about maintaining quality of life; Treves et al. 2013), or natural environment transformation (Buijs et al. 2009). People may perceive heavily-managed landscapes (such as commercial forests or monocultures) as aesthetically pleasing, while natural habitats (such as wetlands or deserts) may appear unattractive (Buijs et al. 2009). Although sense of place conservation does not necessarily match ecologically important ecosystems, peoples' cultural values related to sense of place (Phillips 1998) may promote beneficial opportunities to address threats to biodiversity. As stated by Saunders (2013, p. 17) 'incorporating local cultural aspects into conservation interventions does not necessarily mean privileging local material concerns, but it would mean that local embodied experiences and interests can be more fully integrated into conservation planning decisions'.

\section{CONCLUSION}

Sense of place can potentially provide positive solutions for both human well-being and biodiversity conservation. While sense of place provides a variety of benefits to people in various contexts (Table 1), the economic value of sense of place is usually neglected. Experiencing biodiversity is also an essential component of sense of place and human well-being that needs to be further explored in future studies. Biodiversity loss (for example the loss of iconic species like rhinoceros or elephant; Di Minin et al. 2015) may have negative effects on sense of place, related to changes in environmental qualities and the physical characteristics of places, and loss of peoples' identity, attachment and the meanings attributed to places. At the same time, the 'construction' of a sense of place could sometimes result in an increase in human disturbance and in enhanced threats to biodiversity (via habitat transformation or species introduction). Providing a sense of place experience (through recreation) should have a minimum impact on natural ecosystems.

Improved assessment and knowledge of the benefits that biodiversity-related experiences provide as a sense of place, and the inclusion of these into policies for landuse and resource management planning, could uncover positive benefits for both biodiversity conservation and human well-being. In particular, recognizing the value of sense of place in ecosystem management processes (through environmental impact assessment, land-use planning, ecotourism development, and climate change adaptation) is essential to ensure human access (through sites for outdoor activities, urban green spaces, and cultural landscapes) to sense of place benefits, while promoting biological conservation (by expanding the network of protected areas, enhancing habitat connectivity, promoting sustainable development, and gaining public support; Di Minin \& Toivonen 2015). Our research indicates that sense of place must be integral to the Intergovernmental Platform on Biodiversity and Ecosystem Services (www.ipbes.net). 


\section{Supplementary material}

To view supplementary material for this article, please visit http://dx.doi.org/10.1017/S0376892915000314.

\section{References}

Abraham, A., Sommerhalder, K. \& Abel, T. (2010) Landscape and well-being: a scoping study on the health-promoting impact of outdoor environments. International Fournal of Public Health 55: $59-69$.

Adamowicz, W., Boxall, P., Williams, M. \& Louviere, J. (1998) Stated preference approaches for measuring passive use values: choice experiments and contingent valuation. American fournal of Agricultural Economics 80: 64-75.

Alkan, H., Korkmaz, M. \& Tolunay, A. (2009) Assessment of primary factors causing positive or negative local perceptions on protected areas. Fournal of Environmental Engineering and Landscape Management 17: 20-27.

Andersson, E., Barthel, S. \& Ahrne, K. (2007) Measuring socialecological dynamics behind the generation of ecosystem services. Ecological Applications 17: 1267-1278.

Anderson, B.J., Armsworth, P.R., Eigenbrod, F., Thomas, C.D., Gillings, S., Heinemeyer, A., Roy, D.B. \& Gaston, K.J. (2009) Spatial covariance between biodiversity and other ecosystem service priorities. Fournal of Applied Ecology 46: 888-896.

Armsworth, P.R., Chan, K.M.A., Daily, G.C., Ehrlich, P.R., Kremen, C., Ricketts, T.H. \& Sanjayan, M.A. (2007) Ecosystemservice science and the way forward for conservation. Conservation Biology 21: 1383-1384.

Balvanera, P., Daily, G.C., Ehrlich, P.R., Ricketts, T.H., Bailey, S.A., Kark, S., Kremen, C. \& Pereira, H. (2001) Conserving biodiversity and ecosystem services. Science 291: 2047.

Bateman, I.J., Harwood, A.R., Mace, G.M., Watson, R.T., Abson, D.J., Andrews, B., Binner, A., Crowe, A., Day, B.H. \& Dugdale, S. (2013) Bringing ecosystem services into economic decisionmaking: land use in the United Kingdom. Science 341: 45-50.

Bauer, N., Wallner, A. \& Hunziker, M. (2009) The change of European landscapes: human-nature relationships, public attitudes towards rewilding, and the implications for landscape management in Switzerland. Fournal of Environmental Management 90: 2910-2920.

Bendt, P., Barthel, S. \& Colding, J. (2013) Civic greening and environmental learning in public-access community gardens in Berlin. Landscape and Urban Planning 109: 18-30.

Bickerstaff, K. (2004) Risk perception research: socio-cultural perspectives on the public experience of air pollution. Environment International 30: 827-840.

Borrie, W.T. \& Birzell, R.M. (2001) Approaches to measuring quality of the wilderness experience. In: Visitor Use Density and Wilderness Experience: Proceedings, ed. W.A. Friedmund \& D.N. Cole, pp. 29-38. Missoula, MT. Proceedings RMRS-P-20. Ogden, Utah, USA: USDA Forest Service, Rocky Mountain Research Station.

Boxall, P.C. \& Adamowicz, W.L. (2002) Understanding heterogeneous preferences in random utility models: a latent class approach. Environmental and Resource Economics 23: 421-446.

Brehm, J.M., Eisenhauer, B.W. \& Stedman, R.C. (2013) Environmental concern: examining the role of place meaning and place attachment. Society and Natural Resources 26: 522-538.
Brown, G. \& Raymond, C. (2007) The relationship between place attachment and landscape values: toward mapping place attachment. Applied Geography 27: 89-111.

Buijs, A.E., Elands, B.H.M. \& Langers, F. (2009) No wilderness for immigrants: cultural differences in images of nature and landscape preferences. Landscape and Urban Planning 91: 113-123.

Butchart, S.H., Walpole, M., Collen, B., van Strien, A., Scharlemann, J.P., Almond, R.E., Baillie, J.E., Bomhard, B., Brown, C. \& Bruno, J. (2010) Global biodiversity: indicators of recent declines. Science 328: 1164-1168.

Cardinale, B.J., Duffy, J.E., Gonzalez, A., Hooper, D.U., Perrings, C., Venail, P., Narwani, A., Mace, G.M., Tilman, D. \& Wardle, D.A. (2012) Biodiversity loss and its impact on humanity. Nature 486: 59-67.

Carpenter, S.R., Mooney, H.A., Agard, J., Capistrano, D., DeFries, R.S., Díaz, S., Dietz, T., Duraiappah, A.K., Oteng-Yeboah, A., Pereira, H.M., Perrings, C., Reid, W.V., Sarukhan, J., Scholes, R.J. \& Whyte, A. (2009) Science for managing ecosystem services: Beyond the Millennium Ecosystem Assessment. Proceedings of the National Academy of Sciences USA 106: 1305-1312.

Chan, K.M.A., Pringle, R.M., Ranganathan, J., Boggs, C.L., Chan, Y.L., Ehrlich, P.R., Haff, P.K., Heller, N.E., Al-khafaji, K. \& Macmynowski, D.P. (2007) When agendas collide: human welfare and biological conservation. Conservation Biology 21: $59-68$.

Chan, K.M.A., Satterfield, T. \& Goldstein, J. (2012) Rethinking ecosystem services to better address and navigate cultural values. Ecological Economics 74: 8-18.

Chan, K.M.A., Shaw, M.R., Cameron, D.R., Underwood, E.C. \& Daily, G.C. (2006) Conservation planning for ecosystem services. PLoS Biology 4: e379.

Cheng, T.M., Wu, H.C. \& Huang, L.M. (2013) The influence of place attachment on the relationship between destination attractiveness and environmentally responsible behavior for island tourism in Penghu, Taiwan. Fournal of Sustainable Tourism 21:1166-1187.

Chiesura, A. \& De Groot, R. (2003) Critical natural capital: a sociocultural perspective. Ecological Economics 44: 219-231.

Costanza, R. \& Daly, H.E. (1992) Natural capital and sustainable development. Conservation Biology 6: 37-46.

Cuba, L. \& Hummon, D.M. (1993) A place to call home: identification with dwelling, community, and region. The Sociological Quarterly 34: 111-131.

Daily, G.C., Polasky, S., Goldstein, J., Kareiva, P.M., Mooney, H.A., Pejchar, L., Ricketts, T.H., Salzman, J. \& Shallenberger, R. (2009) Ecosystem services in decision making: time to deliver. Frontiers in Ecology and the Environment 7: 21-28.

De Groot, M. (2012) Exploring the relationship between public environmental ethics and river flood policies in western Europe. Fournal of Environmental Management 93: 1-9.

Devine-Wright, P. (2013) Think global, act local? The relevance of place attachments and place identities in a climate changed world. Global Environmental Change-Human and Policy Dimensions 23: 61-69.

Devine-Wright, P. (2009) Rethinking NIMBYism: The role of place attachment and place identity in explaining place-protective action. Fournal of Community and Applied Social Psychology 19: 426-441.

Dewa, C.S., Lesage, A., Goering, P. \& Caveen, M. (2004) Nature and prevalence of mental illness in the workplace. Healthcare Papers 5: 12-25. 
Di Minin, E. \& Toivonen, T. (2015) Global protected area expansion: creating more than paper parks. BioScience 65: 637-638.

Di Minin, E., Fraser, I., Slotow, R. \& MacMillan, D.C. (2013a) Understanding heterogeneous preference of tourists for big game species: implications for conservation and management. Animal Conservation 16: 249-258.

Di Minin, E., Macmillan, D.C., Goodman, P.S., Escott, B., Slotow, R. \& Moilanen, A. (2013b) Conservation businesses and conservation planning in a biological diversity hotspot. Conservation Biology 27: 808-820.

Di Minin, E., Laitila, J., Montesino Pouzols, F., Leader-Williams, N., Slotow, R., Conway, A.J., Goodman, P.S. \& Moilanen, A. (2015) Identification of policies for a sustainable legal trade in rhinoceros horn based on population projection and socioeconomic models. Conservation Biology 29: 545-555.

Diamond, J.M. (1984) 'Normal' extinctions of isolated populations. In: Extinctions, ed. M.H. Nitecki, pp. 191-246. Chicago, IL, USA: Chicago University Press.

Dumyahn, S.L. \& Pijanowski, B.C. (2011) Soundscape conservation. Landscape Ecology 26:1327-1344.

Egoh, B., Reyers, B., Rouget, M., Bode, M. \& Richardson, D.M. (2009) Spatial congruence between biodiversity and ecosystem services in South Africa. Biological Conservation 142: 553-562.

Egoh, B., Rouget, M., Reyers, B., Knight, A.T., Cowling, R.M., van Jaarsveld, A.S. \& Welz, A. (2007) Integrating ecosystem services into conservation assessments: a review. Ecological Economics 63: 714-721.

Farmer, J.R., Knapp, D., Meretsky, V.J., Chancellor, C. \& Fischer, B.C. (2011) Motivations influencing the adoption of conservation easements. Conservation Biology 25: 827-834.

Feitelson, E. (1991) Sharing the globe: the role of attachment to place. Global Environmental Change 1: 396-406.

Foley, J.A., DeFries, R., Asner, G.P., Barford, C., Bonan, G., Carpenter, S.R., Chapin, F.S., Coe, M.T., Daily, G.C., Gibbs, H.K., Helkowski, J.H., Holloway, T., Howard, E.A., Kucharik, C.J., Monfreda, C., Patz, J.A., Prentice, I.C., Ramankutty, N. \& Snyder, P.K. (2005) Global consequences of land use. Science 309: 570-574.

Foley, J.A., Ramankutty, N., Brauman, K.A., Cassidy, E.S., Gerber, J.S., Johnston, M., Mueller, N.D., O’Connell, C., Ray, D.K. \& West, P.C. (2011) Solutions for a cultivated planet. Nature 478: 337-342.

Fredrickson, L.M. \& Anderson, D.H. (1999) A qualitative exploration of the wilderness experience as a source of spiritual inspiration. Fournal of Environmental Psychology 19: 21-39.

Fresque-Baxter, J.A. \& Armitage, D. (2012) Place identity and climate change adaptation: a synthesis and framework for understanding. Wiley Interdisciplinary Reviems: Climate Change 3: 251-266.

Fuller, R.A., Irvine, K.N., Devine-Wright, P., Warren, P.H. \& Gaston, K.J. (2007) Psychological benefits of greenspace increase with biodiversity. Biology Letters 3: 390-394.

Garcia-Llorente, M., Martín-Lopez, B., Iniesta-Arandia, I., LopezSantiago, C.A., Aguilera, P.A. \& Montes, C. (2012) The role of multi-functionality in social preferences toward semi-arid rural landscapes: an ecosystem service approach. Environmental Science and Policy 19: 136-146.

Gaston, K.J., Ávila-Jiménez, M.L. \& Edmondson, J.L. (2013) Review: managing urban ecosystems for goods and services. Journal of Applied Ecology 50: 830-840.
Goddard, M.A., Dougill, A.J. \& Benton, T.G. (2010) Scaling up from gardens: biodiversity conservation in urban environments. Trends in Ecology and Evolution 25: 90-98.

Gosling, E. \& Williams, K.J.H. (2010) Connectedness to nature, place attachment and conservation behaviour: Testing connectedness theory among farmers. Fournal of Environmental Psychology 30: 298-304.

Grinde, B. \& Patil, G.G. (2009) Biophilia: does visual contact with nature impact on health and well-being? International fournal of Environmental Research and Public Health 6: 2332-2343.

Halladay, P. \& Gilmour, D.A. (1995) Conserving biodiversity outside protected areas: the role of traditional agro-ecosystems. The IUCN Forest Conservation Programme, Volume 20. Gland, Switzerland: IUCN: 228 pp.

Harper, N.J., Russell, K.C., Cooley, R. \& Cupples, J. (2007) Catherine freer wilderness therapy expeditions: an exploratory case study of adolescent wilderness therapy, family functioning, and the maintenance of change. Child and Youth Care Forum 36: $111-129$.

Hartig, T. \& Staats, H. (2006) The need for psychological restoration as a determinant of environmental preferences. Fournal of Environmental Psychology 26: 215-226.

Heller, N.E. \& Zavaleta, E.S. (2009) Biodiversity management in the face of climate change: a review of 22 years of recommendations. Biological Conservation 142: 14-32.

Horwitz, P., Lindsay, M. \& O’Connor, M. (2001) Biodiversity, endemism, sense of place, and public health: inter-relationships for Australian inland aquatic systems. Ecosystem Health 7: 253-265.

Htun, N.Z., Mizoue, N. \& Yoshida, S. (2012) Determinants of local people's perceptions and attitudes toward a protected area and its management: a case study from Popa Mountain Park, central Myanmar. Society and Natural Resources 25: 743-758.

Jorgensen, B.S. \& Stedman, R.C. (2006) A comparative analysis of predictors of sense of place dimensions: attachment to, dependence on, and identification with lakeshore properties. Fournal of Environmental Management 79: 316-327.

Kaltenborn, P. (1998) Effects of sense of place on responses to environmental impacts. Applied Geography 18: 169-189.

Kaplan, R. \& Kaplan, S. (1989) The Experience of Nature: a Psychological Perspective. Cambridge, UK: Cambridge University Press, $340 \mathrm{pp}$.

Kellert, S.R. (1995) The Biophilia Hypothesis. Washington, DC, USA: Island Press: 496 pp.

Kerley, G.I.H., Geach, B.G.S. \& Vial, C. (2003) Jumbos or bust: do tourists' perceptions lead to an under-appreciation of biodiversity? South African Fournal of Wildlife Research 33: 13-21.

Kil, N., Holland, S.M., Stein, T.V. \& Ko, Y.J. (2012) Place attachment as a mediator of the relationship between naturebased recreation benefits and future visit intentions. Fournal of Sustainable Tourism 20: 603-626.

Kuo, F.E. \& Sullivan, W.C. (2001) Aggression and violence in the inner city: impacts of environment via mental fatigue. Environment and Behavior 33: 543-571.

Kweon, B.C., Sullivan, W.C. \& Wiley, A.R. (1998) Green common spaces and the social integration of inner city older adults. Environment and Behavior 30: 832-858.

Larsen, L., Adams, J., Deal, B., Kweon, B.S. \& Tyler, E. (1998) Plants in the workplace the effects of plant density on productivity, attitudes, and perceptions. Environment and Behavior 30: 261-281.

Larson, S., De Freitas, D.M. \& Hicks, C.C. (2013) Sense of place as a determinant of people's attitudes towards the environment: 
implications for natural resources management and planning in the Great Barrier Reef, Australia. Fournal of Environmental Management 117: 226-234.

Leather, P., Pyrgas, M., Beale, D. \& Lawrence, C. (1998) Windows in the workplace sunlight, view, and occupational stress. Environment and Behavior 30: 739-762.

Lewicka, M. (2005) Ways to make people active: the role of place attachment, cultural capital, and neighbourhood ties. Fournal of Environmental Psychology 25: 381-395.

Lohr, V.I. \& Pearson-Mims, C.H. (2006) Responses to scenes with spreading, rounded, and conical tree forms. Environment and Behavior 38: 667-688.

Lokhorst, A. M., Hoon, C., le Rutte, R. \& de Snoo, G. (2014) There is an $\mathrm{I}$ in nature: the crucial role of the self in nature conservation. Land Use Policy 39:121-126.

Lopez-Mosquera, N. \& Sanchez, M. (2013) Direct and indirect effects of received benefits and place attachment in willingness to pay and loyalty in suburban natural areas. Fournal of Environmental Psychology 34: 27-35.

Low, S.M. \& Altman, I. (1992) Place Attachment. New York, NY, USA: Plenum: $336 \mathrm{pp}$.

MA (2005) Ecosystems and Human Well-being: Synthesis. Washington, DC, USA: Island Press.

Mace, G.M., Norris, K. \& Fitter, A.H. (2012) Biodiversity and ecosystem services: a multilayered relationship. Trends in Ecology and Evolution 27: 19-26.

Maller, C., Townsend, M., Pryor, A., Brown, P. \& St Leger, L. (2006) Healthy nature healthy people: 'contact with nature' as an upstream health promotion intervention for populations. Health Promotion International 21: 45-54.

Manzo, L.C. (2006) Finding common ground: the importance of place attachment to community participation and planning. Fournal of Planning Literature 20: 335-350.

Martín-López, B., Montes, C. \& Benayas, J. (2007) The noneconomic motives behind the willingness to pay for biodiversity conservation. Biological Conservation 139: 67-82.

McKenney, B.A. \& Kiesecker, J.M. (2010) Policy development for biodiversity offsets: a review of offset frameworks. Environmental Management 45: 165-176.

Measham, T.G. (2006) Learning about environments: the significance of primal landscapes. Environmental Management 38: 426-434.

Mendoza, C. \& Moren-Alegret, R. (2013) Exploring methods and techniques for the analysis of senses of place and migration. Progress in Human Geography 37: 762-785.

Meurk, C.D., Blaschke, P.M. \& Simcock, R. (2013) Ecosystem services in New Zealand cities. In: Ecosystem Services in Nem Zealand: Conditions and Trends, ed. J.R. Dymond, pp. 254-273. Lincoln, New Zealand: Manaaki Whenua Press.

Milcu, A.I., Hanspach, J., Abson, D. \& Fischer, J. (2013) Cultural ecosystem services: a literature review and prospects for future research. Ecology and Society 18: 44.

Norgaard, R.B. (2010) Ecosystem services: from eye-opening metaphor to complexity blinder. Ecological Economics 69: 12191227.

Pedersen, C.B. \& Mortensen, P.B. (2001) Evidence of a doseresponse relationship between urbanicity during upbringing and schizophrenia risk. Archives of General Psychiatry 58: 1039-1046.

Pejchar, L. \& Mooney, H.A. (2009) Invasive species, ecosystem services and human well-being. Trends in Ecology and Evolution 24: 497-504.
Perreault, T. (2005) Why chacras (swidden gardens) persist: agrobiodiversity, food security, and cultural identity in the Ecuadorian Amazon. Human Organization 64: 327-339.

Phillips, A. (1998) The nature of cultural landscapes: a nature conservation perspective. Landscape Research 23: 21-38.

Pretty, J. \& Ward, H. (2001) Social capital and the environment. World Development 29: 209-227.

Ramkissoon, H., Weiler, B. \& Smith, L.D.G. (2012) Place attachment and pro-environmental behaviour in national parks: the development of a conceptual framework. Fournal of Sustainable Tourism 20: 257-276.

Raymond, C.M., Bryan, B.A., MacDonald, D.H., Cast, A., Strathearn, S., Grandgirard, A. \& Kalivas, T. (2009) Mapping community values for natural capital and ecosystem services. Ecological Economics 68: 1301-1315.

Reichard, S.H. \& White, P. (2001) Horticulture as a pathway of invasive plant introductions in the United States. BioScience 51: 103-113.

Reser, J.P., Morrissey, S.A. \& Ellul, M. (2011) The threat of climate change: psychological response, adaptation, and impacts. In: Climate Change and Human Well-Being, ed. I. Weissbecker, pp. 19-42. New York, NY, USA: Springer.

Rudd, H., Vala, J. \& Schaefer, V. (2002) Importance of backyard habitat in a comprehensive biodiversity conservation strategy: a connectivity analysis of urban green spaces. Restoration Ecology 10: $368-375$.

Russell, R., Guerry, A.D., Balvanera, P., Gould, R.K., Basurto, X., Chan, K.M.A., Klain, S., Levine, J. \& Tam, J. (2013) Humans and nature: how knowing and experiencing nature affect well-being. Annual Reviem of Environment and Resources 38: 473-502.

Saunders, F.P. (2013) Seeing and doing conservation differently: a discussion of landscape aesthetics, wilderness, and biodiversity conservation. Fournal of Environment and Development 22: 3-24.

Schroeder, H.W. (1996) Ecology of the heart: understanding how people experience the environments. In: Natural Resource Management: The Human Dimension, ed. A.W. Ewert, pp. 13-27. Boulder, CO, USA: Westview Press.

Sevenant, M. \& Antrop, M. (2010) The use of latent classes to identify individual differences in the importance of landscape dimensions for aesthetic preference. Land Use Policy 27: 827-842.

Staats, H., Kieviet, A. \& Hartig, T. (2003) Where to recover from attentional fatigue: an expectancy-value analysis of environmental preference. Fournal of Environmental Psychology 23: 147-157.

Stedman, R.C. (2002) Toward a social psychology of place: predicting behavior from place-based cognitions, attitude, and identity. Environment and Behavior 34: 561-581.

Stedman, R.C. (2003) Is it really just a social construction? The contribution of the physical environment to sense of place. Society and Natural Resources 16: 671-685.

Tallis, H., Kareiva, P., Marvier, M. \& Chang, A. (2008) An ecosystem services framework to support both practical conservation and economic development. Proceedings of the National Academy of Sciences USA 105: 9457-9464.

Thwaites, K., Helleur, E. \& Simkins, I.M. (2005) Restorative urban open space: exploring the spatial configuration of human emotional fulfilment in urban open space. Landscape Research 30: 525-547.

Treves, A., Naughton-Treves, L. \& Shelley, V. (2013) Longitudinal analysis of attitudes toward wolves. Conservation Biology 27: 315 323.

Tuan, Y.F. (1977) Space and Place: the Perspective of Experience. Minneapolis, USA: University of Minnesota Press: 226 pp. 
Tuan, Y.F. (1990) Topophilia: A Study of Environmental Perception, Attitudes, and Values. New York, NY, USA: Columbia University Press: 260 pp.

Tzoulas, K., Korpela, K., Venn, S., Yli-Pelkonen, V., Kaźmierczak, A., Niemela, J. \& James, P. (2007) Promoting ecosystem and human health in urban areas using green infrastructure: a literature review. Landscape and Urban Planning 81: 167-178.

Ulrich, R.S. (1983) Aesthetic and affective response to natural environment. In: Human Behavior and Environment: Advances in Theory and Research, ed. I. Altman \& J.F. Wohlwill, pp. 85-125. New York, NY, USA: Plenum Press.

Ulrich, R.S. (1984) View through a window may influence recovery from surgery. Science 24: 420-421.

Um, S. \& Crompton, J.L. (1990) Attitudes determinants in tourism destination choice. Annals of Tourism Research 17: 432-448.

Urquhart, J. \& Acott, T. (2014) A sense of place in cultural ecosystem services: the case of Cornish fishing communities. Society and Natural Resources 27: 3-19.

van den Berg, A.E., Vlek, C.A.J. \& Coeterier, J.F. (1998) Group differences in the aesthetic evaluation of nature development plans: a multilevel approach. Fournal of Environmental Psychology 18: $141-157$. van Riper, C.J. \& Kyle, G.T. (2014) Understanding the internal processes of behavioral engagement in a national park: a latent variable path analysis of the value-belief-norm theory. Fournal of Environmental Psychology 38: 288-297.

van Riper, C.J., Kyle, G.T., Sutton, S.G., Barnes, M. \& Sherrouse, B.C. (2012) Mapping outdoor recreationists' perceived social values for ecosystem services at Hinchinbrook Island National Park, Australia. Applied Geography 35: 164-173.

van Wyk, E., Breen, C. \& Freimund, W. (2014) Meanings and robustness: propositions for enhancing benefit sharing in socialecological systems. International Journal of the Commons 8: 576594.

Weich, S., Twigg, L. \& Lewis, G. (2006) Rural/non-rural differences in rates of common mental disorders in Britain Prospective multilevel cohort study. The British Fournal of Psychiatry 188: 51-57.

White, C., Halpern, B.S. \& Kappel, C.V. (2012) Ecosystem service tradeoff analysis reveals the value of marine spatial planning for multiple ocean uses. Proceedings of the National Academy of Sciences USA 109: 4696-4701.

Williams, D.R. \& Stewart, S.I. (1998) Sense of place: an elusive concept that is finding a home in ecosystem management. Fournal of Forestry 96: 18-23. 